Weiner, Csaba (2021) 'Pathways for a Low-Carbon Electricity System in Poland and Hungary', in Matúš Mišík and Veronika Oravcová, eds, From Economic to Energy Transition: Three Decades of Transitions in Central and Eastern Europe, 211-245, Cham: Palgrave Macmillan.

This chapter was completed on 11 June 2020.

\title{
Pathways for a Low-Carbon Electricity System in Poland and Hungary Csaba Weiner
}

\begin{abstract}
This chapter examines the transition to low-carbon electricity in Poland and Hungary from a security-of-supply point of view. Despite large differences in emphasis, both countries aim to increase electricity generation, decrease import dependence and reduce or eliminate coal-based electricity, while turning to renewables and nuclear energy. In Poland, instead of a coaldominated electricity mix accompanied by wind, natural gas and biomass, a coal-wind-natural gas-nuclear portfolio may emerge by 2040. In Hungary, the nuclear-natural gas-coal-biomass composition is scheduled to transform into a nuclear-solar-biomass-natural gas focus. While electricity is expected to be predominantly low-carbon in Hungary in 2040, such sources may provide only a bit more than half of the Polish power generation.
\end{abstract}

\section{Keywords}

Low-carbon electricity, Security of supply, Stationary fuels, Poland, Hungary

\section{Acknowledgements}

This chapter was supported by the János Bolyai Research Scholarship of the Hungarian Academy of Sciences.

\section{Introduction}

Anthropogenic emissions of carbon dioxide $\left(\mathrm{CO}_{2}\right)$ from burning fossil fuels have become one of the most significant problems of modern civilization (Smil 2010). Since such emissions are the largest contributors to the overall anthropogenic radiative forcing, further temperature increases cannot be limited without a progressive decarbonization of the global energy supply (Smil 2016). Due to the still significant role of fossil fuels, electricity production is the largest emitter of CO2 in the European Union (EU; EEA 2020). Since 2013, however, renewable energy sources (RES) have each year had the highest share in the EU's electricity generation, with 33.0\% reaching in 2018. RES are followed by nuclear energy $(25.3 \%)$, gases $(20 \%)$ and solid fossil fuels, peat, oil shale and sands (19.2\%). The EU's most widely used RES is hydropower $(11.6 \%)$, followed by wind $(11.5 \%)$, solar energy (3.9\%) and solid biofuels (3\%; Eurostat 2020a).

There are, however, considerable variations across EU countries in the use of different energy sources, and differences can also be observed across the Central and East European (CEE) EU member countries. Although Article 194 (2) of the Treaty on the Functioning of the European Union states that member states are allowed to decide between different energy sources and on the general structure of their energy supply (Official Journal of the European Union 2012), EU objectives and obligations limit this sovereignty to some extent. In 2018, 
Hungary had the third lowest share of RES in electricity generation in the EU at $11.8 \%$, behind Cyprus and Malta at 10.1 and 9.4\%, respectively. Among the CEE countries, the share of RES was lower than the EU average in Czechia (11.9\%), Poland (13\%), Estonia (16.1\%), Bulgaria $(20.5 \%)$ and Slovakia (22.7\%). Higher than the EU average values were found in Slovenia (33.2\%), Romania (41\%), Latvia (52\%), Croatia (72.4\%) and Lithuania (83.3\%). In countries with above average shares, hydropower accounts for the vast majority of electricity production. Lithuania is an exception where hydropower and wind energy provide similar shares. Nonetheless, the situation becomes better in CEE if nuclear power is added to RES (Eurostat 2020a).

In this chapter, we examine the current situation and the 2030 and 2040 prospects for the transition to low-carbon energy sources in electricity generation in Poland and Hungary. We assess paths taken by two CEE countries and factors behind the plans and results. The chapter analyses these issues from a security-of-supply point of view.

\section{Methodology and Data}

This chapter employs the conventional three-dimensional approach, encompassing availability, affordability and sustainability, to assessing the security of energy supply. The main focus is on primary energy fuels-RES, nuclear fuel, coal and natural gas - in relation to electricity as a secondary energy source, but the three-dimensional approach is also applied, in part, to electricity itself. Security of supply has no uniform definition. According to the International Energy Agency (IEA), it is the uninterrupted availability of energy sources at an affordable price, while respecting environmental concerns (Jewell 2011). ${ }^{1}$ We argue that this methodology is also appropriate in the case of a country with a securitized energy agenda (i.e., for Poland), and thus geopolitical considerations can be taken into account while keeping the original three-dimensional assessment. Existing literature provides three options of coping with this problem: (i) these geopolitical considerations should represent another distinct (fourth) dimension; or (ii) these aspects could be included under the dimension of availability; or (iii) an attempt should be made not to mix security of supply with geopolitical arguments, thus to treat geopolitical threats as outside the scope of security of supply.

There are several examples of the treatment of geopolitical considerations as a distinct dimension of security of supply, such as Alhajji's (2007) six dimensions (economic, environmental, social, foreign policy, technical and security), Von Hippel et al.'s (2011) comprehensive concept of security of supply (environment, technology, demand-side management, social-cultural factors and international relations or military risks) or the US President's All-of-the-Above Energy Strategy (energy supply availability, reliability, affordability and geopolitical considerations; EOP 2014). Conversely, APERC's (2007) four 'A's of security of supply include geopolitical aspects under the dimension of accessibility. However, Hughes (2012) claims that the omission of accessibility could be justified, since accessibility can be considered as part of availability: if access to an energy flow is problematic, this is reflected in its availability. This indirectly suggests the inclusion of geopolitical aspects under the dimension of availability. In contrast, Dickel et al. (2014) distinguish gas security from among the various geopolitical threats to national security when discussing European dependence on Russian gas.

In opposition to the above-discussed three options, we claim that geopolitics is (part of) an influencing factor, and the prioritization of different dimensions should be made on the basis

\footnotetext{
${ }^{1}$ The IEA does not use the definition consistently, because instead of the three-dimensions above, more recently it uses the original (old) two-dimensional concept (IEA 2020a) and elsewhere other classifications (IEA 2020b).
} 
of such influencing factors as the following: (i) the energy perspective (the energy market supply/demand and price conditions); (ii) the institutional context (the role of the EU); and (iii) the government's approach towards dependence and its perceptions and expectations of threat, as well as its relations with Russia. The geopolitical considerations belong to the third influencing factor.

The dimensional approach differs from that of the EU, since the EU, usually, does not consider the above three dimensions as part of the concept of security of supply, but as the main objectives of the EU's energy policy: security of supply, sustainability and competitiveness.

In this chapter, when evaluating the security of energy supply, we review energy policies and related national and EU documents, as well as statements made by governments and other stakeholders on security of supply. We also analyse stated aspirations and progress made towards enhancing the security of energy supply and examine the reasons behind the results. The main documents, however, are the National Energy and Climate Plans (NECP) that Poland and Hungary submitted to the European Commission (EC) in December 2019 and January 2020, respectively. We rely on the so-called WAM ('with additional measures') scenarios, reflecting additional measures to be taken. While Hungary's new National Energy Strategy was released in parallel with its NECP, the 2009 Energy Policy is still in effect in Poland. The last version of the draft Polish Energy Policy dates to November 2019.

\section{Changing Electricity Balances in Hungary and Poland}

Since 1990, total electricity consumption (the sum of net imports and total gross production) has followed an upward trend - with some slumps - and continues to rise, but at significantly different rates in the two countries. In Poland, in relative terms, considerably lower additional demand is predicted. Here, total electricity consumption could witness 19.3 and $33.9 \%$ increases by 2030 and 2040, respectively, as compared to the 2016 level, according to the Polish NECP (MAP 2019). In Hungary, gross electricity demand-an indicator that is used for forecasts by Hungary's 2020 National Energy Strategy instead of Eurostat's total electricity consumption data-is expected to grow by $39.5 \%$ between 2016 and 2030 and by $60.8 \%$ between 2016 and 2040 (ITM 2020c).

Electricity imports play different roles in the two countries. Poland used to be a net electricity exporter, but it has been a net electricity importer since 2014, with the exception of 2015. Though on the rise, net imports are still considered low compared to consumption, being at $3.2 \%$ in 2018 (Eurostat 2020d). According to its NECP, Poland will remain a net electricity importer until around 2023, while the electricity import-export balance is assumed to be at a level close to zero during the remainder of the period until 2040, which can satisfy the government's desire to reach self-sufficiency (MAP 2019). Nonetheless, low annual net import ratios divert attention from seasonal problems that may occur due to the characteristics of the Polish power sector and a substantial lack of investment in domestic generation, transmission and distribution as well as interconnections (Wierzbowski et al. 2017). Such power shortage was evident in August 2015. The phenomenon of uncontrolled/unscheduled loop flows from Germany to Poland also poses a problem and reportedly blocked imports from neighbouring countries during this crisis (Schlandt 2015). In contrast, the share of net imports in total electricity consumption in Hungary is currently at around 30\%, compared to only $9 \%$ in 2007 and 2008 (Eurostat 2020d), but in Hungary's case substantial cross-border electricity transmission capacity exists. Although high share of electricity imports is largely caused by price competitiveness of imports vis-à-vis domestic production, the problem is that domestic installed generation capacity was unable to meet inland electricity consumption during $21.5 \%$ 
of the time between 2015 and 2018 (Bartek-Lesi et al. 2019). The Hungarian NECP aims at decreasing the import ratio to $20 \%$ by 2040 (ITM 2020b). In the meantime, however, electricity imports will sharply decrease by 2030 due to the construction of new units (Paks II) at Hungary's only nuclear facility, the Paks Nuclear Power Plant (NPP). During the parallel operation of the old and new units, Hungary will become almost completely self-sufficient on an annual basis, but the closure of the old units will again result in increased imports in the second half of the 2030s (ITM 2020b).

Poland and Hungary have utterly different electricity mixes. In 2018, the share of lowcarbon electricity generation in Poland accounted for only $13 \%$, but it reached $61.2 \%$ in Hungary. This was caused by RES in Poland, which also intends to rely on nuclear energy in the future. In Hungary, nuclear energy provided $49.4 \%$ of electricity production in 2018 , while the share of RES amounted to only $11.8 \%$. Poland has been following a trend toward decreasing the role of coal and increasing the significance of RES and gaseous fuels, the latter including both natural gas and manufactured gases. Although Poland does not rely almost totally on coal anymore, solid fuels still accounted for $76.8 \%$ of electricity generation in 2018 , with hard coal and lignite's share at 47.8 and $29 \%$, respectively. This heavy reliance is reflected in low energy import dependence. The share of natural gas stood at $7.4 \%$ in 2018 , compared to $3-4 \%$ in the first half of the 2010 s, $0.9 \%$ in 2001 and $0.1 \%$ in the early 1990 s (Eurostat 2020a). According to the Polish NECP, coal will still dominate the electricity sector in 2030, of which hard coal will contribute by $31.4 \%$ and lignite by $24.8 \%$. In 2040, hard coal will have a share of $20.2 \%$, but the role of lignite will be pushed back to $7.7 \%$. Gaseous fuels are expected to occupy a $10.3 \%$ share in 2030 and $17.0 \%$ in 2040 . The first nuclear unit could enter service in the first half of the 2030s, followed by further units throughout the 2030s and 2040s, allowing to reach a share of $9.6 \%$ in 2035 and $13.6 \%$ in 2040. The share of RES will increase to $31.6 \%$ in 2030 and $39.5 \%$ in 2040 . Therefore, low-carbon electricity will rise to $31.6 \%$ in 2030 and $53.1 \%$ in 2040 (MAP 2019).

In Hungary, two power plants - the Paks NPP and the lignite-fired Mátra Power Plantprovide the bulk of electricity generation. Nuclear energy (as mentioned, with $49.4 \%$ in 2018) is followed by natural gas $(22.7 \%)$ and lignite $(14.2 \%)$. The relative role of nuclear energy, lignite and natural gas has been quite volatile in Hungary's electricity generation in past years, changing with market factors, such as import gas prices, carbon prices and electricity prices (Eurostat 2020a). Hungary's NECP predicts that nuclear will remain the dominant fuel for power generation, accounting for 59\% of the electricity output in 2030 and $46.6 \%$ in 2040 . Due to the planned closure of the Mátra Power Plant, the role of coal will decline to $0.8 \%$ by 2030. In contrast, the share of RES is projected to grow to $19.7 \%$ in 2030 and $44.1 \%$ in 2040 . It is assumed that the role of gas will first increase (to $37.4 \%$ in 2025) and then decline (to $20.6 \%$ in 2030 and $9.3 \%$ in 2040). The combined share of RES and nuclear in the electricity mix is planned to be $78.6 \%$ in 2030 and $90.7 \%$ in 2040 (ITM 2020a).

\section{Low-Carbon Sources}

\subsection{Renewable Energy Sources}

The availability dimension of RES focuses on issues of intermittency, variability and nondispatchability, because the electricity sector is a network industry where system balance needs to be maintained. These pose a challenge for transmission and distribution system operators that concerns both availability and affordability, but flexibility in power grids is often underestimated. Further, technology imports and the availability of certain raw materials are 
also issues (Deák 2018). RES are different in terms of dispatchability; wind and photovoltaic (PV) power are non-dispatchable.

Besides balancing and grid costs, the affordability dimension points to the need for subsidies to develop this energy option. However, data collected by the International Renewable Energy Agency (IRENA) show that the global weighted-average levelized cost of electricity (LCOE) from bioenergy, hydropower, geothermal, onshore and offshore wind was within the range of fossil fuel-fired power generation costs between 2010 and 2018 (IRENA 2019b). Likewise, Lazard (2019) states that technologies such as onshore wind and utilityscale solar continue to maintain competitiveness with the marginal cost of existing conventional generation technologies.

In the case of sustainability, the situation is also not so clear-cut, since non-fossil-fuel power technologies also induce life-cycle greenhouse gas (GHG) emissions. In addition, sustainability questions arise about backup power and energy storage. From among the three dimensions, sustainability is clearly the most neglected issue both in Poland and Hungary. Because of energy independency targets and the aim of preserving coal-based electricity, Poland is a hard-line climate policy opponent. Here, the geopolitical influencing factor works in two directions. Although increasing use of RES can reduce dependence on Russia, Poland also has some fear of foreign (German) technological reliance regarding RES production. It seems that Poland would not have promoted RES if there had been no pressure from the EU (Szulecki et al. 2015). The EU institutional factor is present through commitments and incentives, including renewable targets, the EU ETS and funding. In June 2019, both Poland and Hungary vetoed the 2050 EU target to reduce emissions to net zero, and Poland opted out of this commitment when EU leaders finally agreed in December 2019. Naturally, in June 2019, costs were mentioned as barriers. The Hungarian government argued that it had prevented a 30-40\% rise in electricity bills of households, and its decision had saved its utility cost reduction programme that it introduced for households in 2013 (Bolcsó 2019). However, the question of RES subsidies should be seen in light of the sizeable state aid for the Paks II project, and also taking into account the above-mentioned calculations of IRENA (2019b) and Lazard (2019). The Hungarian government's approach fits better with the old model with baseload power provided by large power plants than with decentralized local energy and fragmented systems. The support of nuclear energy is also associated with this approach. However, EU pressure and incentives, the aim of reducing import reliance and rising competitiveness of RES prompt Hungary to include this energy source more. In contrast, the geopolitical factor seems to have no direct effect on this issue.

Wind energy is the most significant source for renewable electricity generation in Poland while for Hungary it is biomass. In Poland, a fundamental restructuring of the role of different RES has occurred. Before 2007, hydropower ranked first. From 2007 to 2014, biomass played the most significant role. In 2015, wind power came in first. The role of solar energy is still almost invisible (Eurostat 2020a). The Polish government believes that offshore wind energy and solar PV will be the new drivers of renewable electricity. At the same time, the future of onshore wind is uncertain because of changes in regulation. In 2016, restrictive measures on onshore wind were adopted both in Poland and Hungary. Subsequently, such measures were relaxed in Poland, and further positive changes appear to lie ahead, but there is a de facto ban in place in Hungary, with no exceptions and indication of any future changes. Perspectives for biogas use is also favourable in Poland, 2 but biomass and hydropower are not expected to significantly grow (MAP 2019).

While the leading role of biomass has not been questioned so far in Hungary, important changes have taken place in the role of wind and PV. The government has chosen PV as the

\footnotetext{
${ }^{2}$ Biogas is not discussed in this chapter.
} 
RES of the future, providing it the backwind necessary for it to take off. In contrast, as seen, the government does not intend to exploit the remaining wind potential. Hydro potential is also not likely to be utilized, but biomass can continue to expand (ITM 2020a).

The EU's 2009 Renewable Energy Directive specified legally binding country-level 2020 targets for the minimum share of energy from RES in gross final energy consumption: $15 \%$ for Poland and $13 \%$ for Hungary which were increased to 15.85 and $14.65 \%$, respectively by the 2010 National Renewable Energy Action Plans (European Parliament and Council 2009; ME 2010; NFM 2010). The 2018 Renewable Energy Directive established a binding 2030 EU target of at least 32\% share, with no national targets (European Parliament and Council 2018). The Polish target is 23\% (MAP 2019), while Hungary adopted the target of 21\% (ITM 2020b). Both countries believe that they will meet the 2020 targets. However, this is far from certain, since their share only reached $11.3 \%$ in Poland and 12.5\% in Hungary in 2018 (Eurostat $2020 \mathrm{~b}$ ), though several steps have recently been taken in both countries. Nevertheless, most of the RES consumption is and will be concentrated in the heating sector, not in electricity.

\subsubsection{Hydropower}

Hydropower is an old power source that can be used to control the power system. This is an important availability feature, but the main issue with hydropower is sustainability that focuses on land use, wildlife impacts and relatively high life-cycle emissions (Union of Concerned Scientists 2013a). Although limited, hydropower opportunities exist both in Poland and Hungary. However, even this potential has been utilized to a limited extent, since sustainability arguments have the upper hand over both the availability and affordability dimensions. In Poland, there are also some pumped-storage power plants, but as opposed to natural inflows, pumped water is not renewable. The total installed hydropower capacity is $2.4 \mathrm{GW}$, out of which the renewable part accounts for slightly less than $1 \mathrm{GW}$. Different sources suggest that around $20 \%$ of the renewable hydropower technical potential is utilized in Poland (Steller 2019; ŚCITT 2020). Over $75 \%$ of the potential is in the Vistula catchment area. The Vistula River itself represents half of the Polish hydropower potential. The Oder River with its tributaries contributes with a further 20\% (Steller 2012). According to Majewski (2013), Polish strategic development documents refer to the need to increase the retention storage capacity for the water reservoirs, which would result in substantial opportunities for electricity generation. Obstacles include the restrictive environmental law and lack of political will. The Polish NECP suggests that installed hydropower capacity will increase from $964 \mathrm{MW}$ in 2015 to $1150 \mathrm{MW}$ in 2030 and $1230 \mathrm{MW}$ in 2040 (MAP 2019).

At the end of 2018, Hungary's installed hydropower capacity amounted to only 58 MW (MEKH-Mavir 2019). The hydropower potential is calculated at $989 \mathrm{MW}$. The Danube River offers almost three quarters of this potential, followed by the Tisza and the Dráva, with the former having the most installed capacity. Hydropower production on the Danube is negligible, while the Dráva has not been exploited at all (Büki and Lovas 2010). While some increase cannot be ruled out in small and medium hydropower capacity, larger-scale projects have been politically unacceptable since the failure of the Gabčíkovo (Slovakia)-Nagymaros (Hungary) Dam on the Danube. In this case, the construction on the Hungarian side was stopped in 1989 as a result of protests by environmentalists and civilians, and despite the 1997 ruling of the International Court of Justice in The Hague, requiring meeting the original treaty, no bilateral compromise has been reached, and thus Hungary does not even receive its share of electricity production from the Gabčíkovo Hydropower Plant. While the use of hydropower on the Danube along the common border between Hungary and Slovakia cannot be carried out without Slovakia's consent, the utilization of the Danube section between the Danube Bend 
and the southern border is not restricted by other countries. Constraints arise from the plan of the Danube Commission, an international intergovernmental organization, in which the locations of the dams allowing navigation have been designated at the city of Adony and the village of Fajsz (Szeredi et al. 2010). At the southern border, neighbour-related problems also affect hydropower development. Investigating the economic feasibility of hydropower plants at Nagymaros and Fajsz, Kerényi and Szeredi (2012) found that they could be implemented and would not require subsidies. The question of pumped-storage hydropower arises occasionally in Hungary, but advocates of environmental sustainability oppose this initiative. Two possible locations are the Danube Bend and the Zemplén Mountains in Northeast Hungary.

\subsubsection{Biomass}

Biomass is an exhaustible RES (Dinya 2010). One of its benefits is its role as a buffer, as it can be stored and dispensed (Dinya 2018). Biomass can be considered as a relatively easy way to increase RES, but the affordability dimension is strongly determined by the feedstock and the applied technology. One way is co-firing, though this decreases the efficiency and lifetime of boilers that were principally designed for coal use (Wierzbowski et al. 2017). As to its sustainability dimension, replacing coal or natural gas with biomass theoretically results in reduced carbon emissions, since, by law, burning wood is carbon neutral, but the time needed for forests to reabsorb the $\mathrm{CO} 2$ emitted during biomass combustion ranges from decades to hundreds of years (EASAC 2018). Additionally, the distances for biomass transportation and imports to the energy plants are both sustainability and affordability issues.

Biomass co-firing had long been profitable due to the old Polish RES support scheme, a factor when evaluating the affordability dimension. Biomass imports were also given a boost, which increased Poland's dependency (Wierzbowski et al. 2017). This affected the availability dimension of supply security. In 2015, installed biomass electricity capacity was the same (553 MW) in Poland and Hungary. The Polish NECP would see an increase in this capacity to reach $1.5 \mathrm{GW}$ in 2030, and then a decline to $1.3 \mathrm{GW}$ in 2040 (MAP 2019). Much less increase is expected in Hungary, as its projected figures are 796 MW in 2030 and 862 MW in 2040 (ITM 2020a). In Hungary, experts and policymakers warn about both the feedstock and the technology. Dinya (2018) recommends not giving preferential treatment to the production of biomass for energy purposes and concentrating instead on the energy utilization of by-products produced when making biomass (and by human activity), as there is always a by-product. Biomass (as raw material) cannot be used for energy purposes without significant expenditure, which should be taken into consideration when evaluating the affordability dimension. Therefore, within the biomass potential, Hungary's National Renewable Energy Utilization Action Plan for 2010-2020 aims at promoting the use of by-products and residues both for biogas and incineration applications. It intends to base the use of biomass for energy generation on new premises. Rather than large power plant capacities, it supports biomass use for the local generation of heat. With respect to electricity, low to medium capacity plants with a local regional development impact should be supported (NFM 2010). Similarly, Büki and Lovas (2010) recommend that to achieve the greatest possible natural gas substitution, biomass should primarily be used for direct heat supply and cogeneration. Due to their low efficiency, direct electricity production from wood and straw-fired power plants are bad solutions. 


\subsubsection{Wind Energy}

When evaluating the availability dimension of wind energy, we concentrate on the wind potential and equipment/technology imports. Wind energy is highly dependent on weather conditions and the wind is usually stronger at night when less power is required. Since wind energy output cannot be forecast precisely, balancing is an important issue with high costs. As the 'fuel' is free, affordability questions point to the price and cost of wind electricity. The lifetime of a wind turbine is around twenty-five years, and the payback period can vary; however, generation costs are very low afterwards. Sustainability problems include high landuse intensity, aesthetic effect, shadow-flickers, noise, negative effects on the flora and fauna as well as icing problems on turbine blades (Szalai et al. 2010).

Poland's wind conditions are relatively ideal for wind energy development, though they vary regionally (Hajto et al. 2017). Poland's installed wind capacity jumped from only $18 \mathrm{MW}$ at the end of 2001 to $5.7 \mathrm{GW}$ at the end of 2016, and 5.9 GW at the end of 2019 (Statista 2020). Due to the spectacular rise observed until 2016, Poland has the eighth largest wind power capacity in the EU. Nevertheless, taking effect in 2016, a new act on investments in wind power plants introduced restrictions due mainly to citizens' complaints about noise. Nonetheless, in 2018 and 2019, the respective acts were, to some extent, relaxed to encourage further wind development. The November 2018 auction showed that onshore wind was very competitive on price, cheaper than new coal and nuclear (WindEurope 2019). The Polish NECP still believes that increases in onshore wind energy will be able to make a key contribution to fulfilling the 2020 target of $9.5 \mathrm{GW}$. However, only a minor further increase is planned until 2040 (MAP 2019). Regarding the technology, at the end of 2015, the Danish manufacturer Vestas enjoyed the leading position (38\%) among manufacturers with the highest installed capacity in Poland, followed by the Spanish Gamesa (now Siemens Gamesa, 14\%) and the American GE (13\%; PSEW 2016). Used wind turbines have been imported from Germany and Denmark (Friends Against Wind 2016).

Poland has no offshore wind energy, but it has the potential to become a leader for which the Baltic Sea offers favourable conditions (McKinsey \& Company 2016), and according to Polish NECP the installed capacity could be $3.8 \mathrm{GW}$ in 2030, 5.7 GW in 2035 and $8.0 \mathrm{GW}$ in 2040 (MAP 2019). Recent years have brought about significant changes in the question of reliance on foreign technology/equipment in offshore wind. The country has become a strong player in the supply chain with major investments in the manufacturing of turbine foundations and the cranes and jack-up vessels used in installation and maintenance. The Polish wind industry, which provides 12,000 jobs, could deliver up to $50 \%$ of the components required to build offshore wind farms (WindEurope 2018).

In contrast, wind power is a big loser in Hungary. In 2016, a de facto ban was introduced on new wind projects, with no new permits issued since 2006. Due to weather conditions, wind turbines are employable only in 5.5 to $6 \%$ of Hungary's territory, but this potential has so far not been exploited (Munkácsy 2015). Latest calculations indicate that the amount of capacity that can be installed by 2050 is $9.5 \mathrm{GW}$ ( $\pm 15 \%$; Munkácsy et al. 2014). In contrast, the last turbine was launched in 2011. At the end of 2018, the installed capacity was 324 MW (MEKHMavir 2019). The annual load factor ranged between 21 and 26\% during the 2010s (ibid.), a good result compared to other European countries (Tóth and Schrempf 2013). Currently, the government claims wind is not optimal for Hungary and thus wind energy has no place in the Hungarian energy system (Német 2016). The government's approach was quite different in 2010. Hungary's National Renewable Energy Utilization Action Plan for 2010-2020 declared that capacity could grow to 740 MW by 2020 (NFM 2010). However, according to the Hungarian Wind Energy Industry Association, the capacity could be increased to $1.2 \mathrm{GW}$ without jeopardizing the operation of the electricity system (Illés 2017). In 2009, the left-wing 
government launched a tender for the development of wind farms with a total capacity of 410 MW (Tóth et al. 2011), but this was then cancelled by the new Orbán government in 2010.

There have been various explanations for the Orbán government's anti-wind energy approach. Besides the argument of the preservation of the natural landscape, the government raised the issue of balancing, the problems of unintended flows and the need for a pumpedstorage hydropower plant as backup capacity - all of them exaggerated compared to the previously planned relatively low capacity. Allegations have been made regarding the political aspects of the issue, as Hungary's wind power sector is linked to the left-wing government. Another problem could be the high share of foreign ownership, low employment in the sector, utilization of foreign technology and low participation by domestic manufacturing companies. Finally, a further explanation could be avoiding disruptions for the Paks II electricity market (Nagy 2016). Regarding affordability, operators receive a higher-than-market price under a feed-in tariff scheme until the return on investment is achieved, after which they sell their electricity on the free market. In 2011, the Hungarian Wind Energy Industry Association argued that paid-off wind power plants sold their electricity on the free market at a price similar to that of the electricity produced by the Paks NPP (MSZIT 2011).

\subsubsection{Photovoltaic Energy}

The availability dimension of PV energy supply security consists of both the amount of solar radiation and technology imports. Poland has similar, and Hungary has better, solar exposure conditions than that of Germany, a world leader in terms of PV capacity (Majewski and Szymanek 2012; Munkácsy et al. 2014). Regarding sustainability, the environmental impacts of solar power include land use in the case of large utility-scale PV and hazardous materials resulting from the PV cell manufacturing process (Union of Concerned Scientists 2013b).

In Poland, solar PV energy was almost non-existent before 2014, but it has grown considerably since 2015. A cumulative capacity of about $500 \mathrm{MW}$ was installed in Poland by the end of 2018, and more than 700 MW by May 2019 (IEO 2019). The Polish NECP predicts that PV capacity could grow to $2.3 \mathrm{GW}$ in 2020, $7.3 \mathrm{GW}$ in 2030 and $16.1 \mathrm{GW}$ in 2040, resulting in a $1.1 \%$ share in electricity generation in 2020, 3.4\% in 2030 and $6.6 \%$ in 2040 from $0.2 \%$ in 2018 (MAP 2019; Eurostat 2020a). While solar PV will have the largest installed capacity in the Polish power sector in 2040, a utilization rate of only $10-11 \%$ is calculated in the 2018 draft Energy Policy (ME 2018). In Hungary, the load factor of electricity generation from PV was $15.2 \%$ in 2018, and by the end of 2018, the installed capacity of PV generation amounted to $726 \mathrm{MW}$ (of which the capacity of small-scale household installations was 332 MW), compared to just 2 MW in 2010 (MEKH-Mavir 2019; IRENA 2019a). The industry is currently experiencing rapid growth. Preliminary data for June 2019 show total PV capacities increasing to $1.1 \mathrm{GW}$ (MEKH 2019). The Hungarian NECP predicts that installed PV capacity will increase to $1.2 \mathrm{GW}$ in 2020 , but then to $6.5 \mathrm{GW}$ in 2030 and $12.0 \mathrm{GW}$ in 2040. Consequently, the technology's share in electricity generation will increase from $1.9 \%$ in 2018 to $3.9 \%$ in $2020,11.5 \%$ in 2030 and $29.3 \%$ in 2040 (ITM 2020a; Eurostat 2020a). These are realistic targets despite negative developments that include long and cumbersome licensing and a tax on solar PV panels (HVG.hu 2017). Positive changes in the solar PV sector are mainly linked to the subsidy system. Nevertheless, high Hungarian figures might have consequences for the electricity system.

The availability dimension is also affected by the dependence on technology imports. Most recent data show that in Poland 60\% of PV modules come from Polish producers, while the rest is imported. In 2016, China had the largest share in imports (36.3\%), followed by Germany (24.8\%; IEO 2017). In contrast, failures are detected in the production of PV panels in 
Hungary. According to the Hungarian Photovoltaic and Solar Collector Association, PV panel production is almost impossible without state support (Szabó 2017). Büki and Lovas (2010) claim that in the domestic PV programme, research and development plays an important role, and the Hungarian PV industry has significant scientific background support and can provide high value added.

\subsection{Nuclear Energy}

The availability dimension of nuclear energy supply security points to the availability of nuclear fuel in sufficient quantities at the site, the possibility of diversifying nuclear fuel and the characteristics of NPPs. Nuclear facilities are inflexible and large. The latter means that problems with a unit (including delays in construction) could cause the loss of a large amount of generation capacity. The affordability dimension requires finding a financing model, producing a positive return on investment and not being classified by the EC as illegal state aid. The development of an NPP requires a large amount initial investment but can then produce for a long time and cheaply (Deák 2018). RES have the lowest variable costs, followed by nuclear energy. The sustainability dimension is supported by the very small amount of emissions, while problems are centred on safety and the management of spent fuel and radioactive waste. Handling these remains an expensive challenge (with no final repository for high-level nuclear waste in any country); decommissioning of an NPP also comes at a huge cost.

Poland has no nuclear capacity. A resolution was adopted to develop the Polish Nuclear Energy Programme in 2009, and the government designated the state-owned PGE Polska Grupa Energetyczna S.A., Poland's largest power producer, as responsible for the set-up and implementation of the programme. Therefore, first, in December 2009, PGE Energia Jądrowa (PGE EJ) S.A. was established, and then, in 2010, PGE EJ 1 Sp. z o.o., as a special-purpose vehicle, was founded with $51 \%$ equity from PGE EJ S.A. and $49 \%$ from PGE S.A. After years of negotiations, it was only in 2014 that PGE S.A. concluded a shareholders' agreement with Enea, KGHM Polska Miedź, Tauron Polska Energia (the first is a majority state-owned Polish company, while the other two are minority state-owned) for the sale of $10 \%$ interest in PGE EJ 1 to each new party. In 2014, the Polish Nuclear Energy Programme was approved. The years 2018 and 2019 have seen a surge of news about the future role of PGE, another three companies and further potential participants in the project, but practically nothing happened. Decisions concerning the financing model, the technology (the general contractor) and the location are still pending. According to the Polish NECP, the first unit with a capacity of 1$1.5 \mathrm{GW}$ should be commissioned in 2033, while the next five units with a combined capacity of 6-9 GW would be launched at intervals of 2-3 years (MAP 2019).

When considering the Russian factor, one should note that the list of nuclear fuel and reactor suppliers is very limited and commitment to one type of reactor assumes a very long-term cooperation between the supplier and the host state (Deák 2018) which excludes the Russian technology. Heinrich et al. (2016) find that nuclear energy is presented in the Polish media as an answer to Poland's energy dependence problems.

Hungary has four Soviet-designed units (500 MW each) in state ownership which are scheduled to be phased out in the 2030s. Based on the government's 2014 decision, the new nuclear project relies on Russian technology, fuel and financing. Two new units, with a slightly higher combined capacity compared to the old units (1.2 GW each), will be built to be owned by the Hungarian state. Their commissioning was postponed from 2024 and 2026, respectively, to 2029 and 2030, but it is still uncertain when they will be online. Seemingly, the geopolitical factor has no negative impact on the project, though the deal will increase 
Hungary's reliance on Russia. Regarding the availability dimension, the government contends that Paks II will increase security of supply, as nuclear fuel will be available in sufficient quantities at the site. But there is no possibility of the diversification of nuclear fuel supplies for this type of reactor. However, as opposed to the old Paks units, the? new units will be technically capable of more flexible operation. Another issue is the availability of sufficient amounts of cooling water from the Danube River.

The affordability of electricity from Paks II, which hinges on two promises made by the Hungarian government - cheap electricity and a profitable project — will hardly be fulfilled. The Russian side provides a $€ 10$ billion credit line for the $€ 12.5$ billion project (Paks II 2020). The interest rate level on the loan seemed advantageous in 2014, but the situation has changed since then. The EC concluded the project would not be profitable on a market basis (EC 2017). The EU institutional factor is apparent in the commitments the Hungarian government had to make to limit potential distortions of competition. Finally, regarding the sustainability dimension, most of the spent nuclear fuel was shipped back to the Soviet Union and Russia between 1989 and 1998. Under normal circumstances, spent fuel is first placed in spent-fuel pools for a minimum of three years and then stored in the Interim Spent-Fuel Storage Facility near Paks for approximately fifty years (OAH 2011). Spent fuel from Paks II can be shipped to Russia for temporary technological storage or reprocessing. Their conditions will be specified in a separate contract.

\subsection{Fossil Fuels}

\subsubsection{Coal}

While coal has favourable properties regarding availability, the opposite is true for sustainability. Nevertheless, it is necessary to make a differentiation between hard coal and lignite, the latter being the lowest grade coal with a very high sulphur content and high $\mathrm{CO}_{2}$ emissions. Lignite is mostly mined in opencast/surface mines; therefore, sustainability issues could appear more directly here. They may include social conflicts when buying agricultural land from farmers for opencasts (and perhaps the resettlement of the rural population living in the area) and environmental impacts (noise and dust; changes in the geological and hydrogeological conditions in the area; and the creation of external dumps to store overburden; Widera et al. 2016). In contrast to hard coal, lignite has limited foreign trade. Affordability is strongly affected by domestic production conditions besides carbon, electricity and international coal prices.

Poland is the tenth largest hard coal producer in the world and the largest in the EU. Between 1990 and 2016, hard coal production decreased by 2.3-fold, and the number of employees dropped from 416,000 to about 85,000 (PSG 2017b). Hard coal mining is still indirectly responsible for an additional 300,000 jobs (Adamczewski 2015). Among this sector's major problems are the high costs of mining, high social costs, low labour productivity, geological factors and quality issues (Kamola-Cieślik 2017). Hard coal industry relies heavily on subsidies. Strong unions and high state ownership level are major factors for restructuring. In the mid-2010s, Poland's Law and Justice government pledged to save the coal industry, as well as modernizing existing coal power plants and building new plants (Wood et al. 2017), but in 2017, a fundamental change was seen in the government's rhetoric when it declared that the new hard-coal unit at the Ostrołęka Power Plant would be the last coal investment (Ciepiela 2017). Finally, in February 2020, the government announced to suspend funding for this power plant, which could mean that a new hard-coal unit soon to be finished at the Jaworzno III Power Plant in 2020 could be Poland's last (Martewicz 2020). The last 
lignite-fired generation unit is being developed at the Turów Power Plant. According to the Polish NECP, the installed capacity of existing hard coal power plants will drop from $13.6 \mathrm{GW}$ in 2015 to $8 \mathrm{GW}$ in 2030 and $3.2 \mathrm{GW}$ in 2040 , while new hard coal power plants (planned or under construction) are to have an installed capacity of $3.5 \mathrm{GW}$ in 2020 and $4.5 \mathrm{GW}$ in 2025 . The installed capacity of hard-coal-based combined heat and power plants is forecast to decrease from 4.7 GW in 2020 to $3.5 \mathrm{GW}$ in 2030 and $2.7 \mathrm{GW}$ in 2040. Throughout the period, capacities at industrial power plants will remain relatively stable at slightly below 2 GW (MAP 2019).

It was only at the beginning of the 2000s that Poland started to import thermal (steam) coal, but in 2008, for the first time, Poland imported more hard coal than it exported (PSG 2017a). Increasing coal imports could lead to higher Russian coal dependence, but this could be perceived differently than gas, since Russian coal imports can be replaced in their entirety in the event of a conflict (Baca-Pogorzelska 2018). Nonetheless, concern has recently been voiced over increasing amount of Russian coal imports and illegal anthracite coal imports coming indirectly from Donbas. ${ }^{3}$ As for lignite, Poland is the sixth largest producer worldwide and the second in the EU. Lignite production has only slightly decreased during the last period (Szczepiński 2016). However, compared to 27,000 in 1991, only 10,000 people are now employed in lignite mining (Schwartzkopff and Schulz 2017). Yet, reportedly, the sector indirectly employs 100,000 people (Adamczewski 2015). Lignite mining has more private ownership than the hard coal sector. In order to maintain the level of lignite mining, new deposits will be exploited, and production will drop significantly only after 2030 (MAP 2019). The affordability dimension is associated with the facts that lignite is cheaper than domestically sourced hard coal (Larson 2018), and the cost of producing electricity from lignite is much lower compared to hard coal (Szczepiński 2016). The combined share of hard coal and lignite in electricity generation will reach $56.2 \%$ in 2030 , before declining to $37.9 \%$ in 2035 and $27.9 \%$ in 2040 (MAP 2019).

In Hungary, the issues of domestic coal mining and coal-fired power generation are centred on the Mátra Power Plant that is supplied from its two open-pit lignite mines. Besides this power plant, there are only two other installations in Hungary that burn coal, but not as the main fuel. Therefore, there does not appear to be any dependence on Russian coal. The Mátra Power Plant is outdated, producing high levels of emissions and requiring costly investment. It is Hungary's single largest emitter of $\mathrm{CO} 2$, being responsible for approximately $10 \%$ of all emissions. Affordability is not an issue for domestic lignite. Profitability depends primarily on electricity and carbon prices, which developments have resulted in huge losses for the power plant in recent years. Licences of the lignite-fired units will expire by the mid-2020s. Since 2020 , the power plant has been state-owned again, so now its fate is entirely up to the government. This is, however, not just about lost generation capacities and the mines, but also about regional employment, including employees at industries settled near the power plant to process its by-products, in addition to 2100 people employed by the power plant and the mines (Mátrai Erőmü 2020). The Hungarian NECP established 2030 as the year for achieving a lignite-free power sector (ITM 2020b), but in February 2020 the respective minister mentioned 2025 as the final year for the lignite units (Marczisovszky 2020). Current biomass co-firing, the company's PV activity and plans for new capacities indicate a move towards sustainability. Biomass is also important from the point of view of the affordability dimension, as due to this the power plant is one of the largest beneficiaries of the RES support system (Greenpeace Hungary 2018). The Hungarian government still views lignite as a buffer to be used in the case of an energy crisis related to availability and affordability, but it is more than questionable if substantial additional coal volumes can be mobilized and utilized in an emergency.

\footnotetext{
${ }^{3}$ Email communication with Miłosława Stępień, 14 August 2018.
} 


\subsubsection{Natural Gas}

Natural gas is the cleanest fossil fuel, but issues of availability, affordability and geopolitics have deteriorating effects on its future. Availability problems include transit crises of Russian gas to European consumers, while affordability-related problems refer to high gas prices between 2011 and 2014. Geopolitical considerations, heated by widely debated issues such as energy/gas weapon/diplomacy, have been exacerbated by the Russian military intervention in Ukraine.

Only a small portion of total natural gas consumption is used to generate electricity in the two countries, but with different consumption histories. In Poland, gas-based power generation barely existed at the beginning of the 1990s but began to pick up in the early 2000s. Albeit with fluctuations, growth trend has been observed since then (Eurostat 2020a), and as indicated, gas-based electricity is becoming more important as the role of coal decreases and the growing presence of RES in the grid also requires more gas, allowing for more flexible balancing. Gas-based electricity is expected to jump from 6.4 TWh in 2015 to 12 TWh in 2020, 20.7 TWh in 2030 and 38.4 TWh in 2040 (MAP 2019). In contrast, already at the time of the change of regime, significant gas-based electricity generation had been taking place in Hungary, which then increased spectacularly until 2007. However, due to the economic crisis of 2008-2009 and, even more importantly, high gas prices, by 2014 production had fallen to less than a third of what it was during the peak year of 2007 when gas was the largest source of Hungary's electricity generation. Since 2015, the trend has shown an upturn (Eurostat 2020a), which might be maintained until the mid-2020s, before a downward trend begins. This trend will be associated with the period of significant PV capacity entering the grid, the commissioning and decommissioning of new and old nuclear units, respectively, and of the shutdown of lignite capacities. After that, in relation to natural gas, the greater level of flexibility will be appreciated, as flexible backup generation capacity will be required (reflected in the following power plant generation figures $-5.1 \mathrm{TWh}$ in $2015,11.6 \mathrm{TWh}$ in 2020, 11.8 TWh in 2030 and 3.8 TWh in 2040; ITM 2020a).

In Poland, domestic gas production is showing a slight decline, but according to the NECP it will remain at its current level until 2040. Increasing gas consumption has resulted in declining production-to-consumption ratio. Currently, it is falling towards 20\% (MAP 2019; Eurostat 2020c). In Hungary, this has already fallen below $20 \%$ as Hungarian gas production was declining rapidly until 2015. Since then, nonetheless, it has grown slightly (Eurostat 2020c), and Hungary's NECP believes that by 2030, natural gas production may continue to grow (ITM 2020b). The future of gas consumption is greatly influenced by the evolution of gas import source diversification and transit diversification, which affect both availability and affordability. Although to varying degrees, both countries are still dependent on Russian gas supplies. Nevertheless, this has been changing recently. Being on the extreme side, Poland aims not to extend its long-term gas supply contract with Russia's Gazprom when it expires in 2022. It is to replace Russian gas mainly with that of Norway via a yet-to-be-built pipeline and with liquefied natural gas (LNG). In contrast, the Hungarian government again intends to conclude a new long-term supply contract with Gazprom for the post-2021 period.

In the 2010s, notable steps have been made to achieve geographical gas import source diversification in Poland. Since 2016, Poland has been able to import non-Russian gas not only by pipeline but also as LNG. Many LNG supply contracts have been signed in securing large quantities. Via pipeline, Poland can buy gas from the east, west and south, but as opposed to virtual capacities, physical capacities are very limited at the southern and western borders. Further pipeline and LNG plans or projects are also in the pipeline, but there could be questions about the affordability dimension either in the case of the Norwegian pipeline gas or that of 
the LNG. An additional important problem regarding affordability is the lack of a competitive gas market in Poland.

Since the late 2000s, Hungary has made significant steps in increasing cross-border pipeline capacities. Currently, Hungary has pipeline links with all neighbouring countries except Slovenia. The Austrian interconnection has remained the most important one for non-Russian imports, allowing for cheaper gas from Western Europe. The Croatian-Hungarian pipeline could be important for gas deliveries from the future Croatian LNG regasification facility, but the LNG price might be a problem. Hopes have long been high regarding the future Romanian Black Sea gas arriving through the Romanian-Hungarian pipeline, but the offshore project has stalled, though competitive gas prices were expected and thus availability and affordability of gas could have also been improved. Nevertheless, both pipeline projects require further investments. The Polish and Hungarian gas infrastructure projects have typically been supported by or eligible for financial support from the EU, pointing to the importance of the institutional context.

Finally, transit diversification is an issue mainly for Hungary. Poland is an important transit country and it has shown strong opposition to the Russian-led Nord Stream 1 gas pipeline and Nord Stream 2 gas pipeline project between Russia and Germany. Hungary also opposes the project, but supports the southern gas transit diversification through Russia's TurkStream pipeline, stretching from Russia to Turkey across the Black Sea. One problem is that Nord Stream 2 would increase gas prices for Hungary (Kotek et al. 2017). A further problem is that, compared to Russian gas imports, the capacities represented by western and northern interconnectors are preferable for import source diversification strategies.

\section{Summary and Conclusions}

Climate change and the transition to low-carbon energy sources have recently received increased attention both in Poland and Hungary due to extreme weather events. While sustainability is expected to be increasingly reflected in policy, industry and public decisions, moving away from old structures will happen slowly and with limited engagement. The starting points for the two countries are mostly different, but despite their varying conditions and priorities, they still have a lot in common. In both countries, electricity consumption is increasing, although to different degrees. To ensure the demand is met, significant power generation capacity needs to be replaced both in Poland and Hungary, but differences are apparent in the degree of obsolescence in their power plant fleets and of self-sufficiency in electricity. Further, we find differences in networks, including cross-border transmission capacities. Similar initial conditions are observed in the low share of RES in electricity generation, but the role of low-carbon electricity generators is high in Hungary due to nuclear energy, while nuclear energy is only in a planning stage in Poland. Another difference is that coal-based electricity generation plays a key role in Poland where everything revolves around coal. Differences are also recorded in the use of natural gas. The prevailing large role of traditional structures in the two countries will decrease due to RES, but the introduction of nuclear energy in Poland and the continuation of nuclear power generation in Hungary will have opposite effects.

From a 2030 perspective, the additional electricity generation is expected in Poland to be mostly satisfied from wind energy and gas, and to a lesser extent from PV, a late arrival on the scene. From a 2040 perspective, nuclear power will be added to the mix with wind energy being the most significant source by then, with nearly the same share as hard coal and lignite combined. Offshore wind power will enter the grid by the mid-2020s and will expand impressively, while onshore wind power generation will stagnate. Domestic industry can 
benefit both from offshore wind and solar PV expansion. Natural gas is also expected to play a significant role in Poland in the long run, as an important tool in reducing coal-based power generation, and not only a flexible complement to variable and intermittent renewables RES. Biomass and hydropower are forecast to see only slight increases, but biogas may become noticeable. Therefore, instead of a coal-dominated electricity mix accompanied by wind, natural gas and biomass, a coal-wind-natural gas-nuclear portfolio may emerge by 2040 . Low-carbon sources may provide only a bit more than half of the Polish power generation, and the share of coal will still be very high in 2040.

PV will play similar role in Hungary to wind in Poland. In addition to PV, retiring lignite capacity will be replaced by gas until new nuclear capacity starts operation. After that, gasbased capacity can be reduced and play a substantial role alongside RES. While the contribution of biomass will also increase, wind and hydropower potential will remain untapped. Consequently, the current nuclear-natural gas-coal-biomass composition is scheduled to transform into a nuclear-solar-biomass-natural gas mix. Electricity is expected to be predominantly low-carbon in Hungary by 2040.

The future of the electricity mix in both countries might be chiefly dependent on purely political decisions, and only to a limited extent on energy market developments. Among the influencing factors, the institutional factor plays a particularly important role in both Poland and Hungary. Nevertheless, the emphasis on geopolitics is very different in the two countries. While Poland has a securitized energy policy, the geopolitical factor has no significant impact on energy policy decisions in Hungary. Poland is concerned with the availability and affordability of Russian gas supplies and reliance on foreign renewable technology, while Russia could not be assigned a role in the case of nuclear energy. Reliance on coal provides low energy import dependence in Poland, and this reliance has been cemented by both the coal industry itself and the geopolitical factor. In the past, energy market factors were dominant, primarily due to prioritization of the affordability dimension, but recently, signs of a shift have started to appear towards availability, mostly reflected in gas import source diversification efforts. Nonetheless, the affordability dimension is the most difficult to assess. While most focus is on the extra RES costs linked to their support, necessary investment in network development and managing variability and intermittency, total costs of electricity from RES are declining and becoming increasingly competitive with coal and nuclear energy that are also subsidized in various ways. In Hungary, a high emphasis has been given to affordability when it comes to end-user prices since 2013. However, it would be a mistake to accept governments' plans as something that will definitely happen since the factors influencing transition pathways for low-carbon electricity generation are subject to changes and reprioritization.

\section{References}

Adamczewski, T. (2015, November 24). Poland's Approach to the Paris COP. Heinrich-Böll-Stiftung. https://www.boell.de/en/2015/11/24/background-polands-approach-paris-cop. Accessed 30 May 2020.

Alhajji, A. F. (2007). What Is Energy Security? (4/5). Middle East Economic Survey, 50(52). http://archives.mees.com/issues/206/articles/7943. Accessed 4 June 2020.

APERC. (2007). A Quest for Energy Security in the 21 st Century: Resources and Constraints. Asia Pacific Energy Research Centre. http://aperc.ieej.or.jp/file/2010/9/26/APERC_2007_A_Quest_for_Energy_Security.pdf. Accessed 31 May 2020.

Baca-Pogorzelska, K. (2018, April 9). Znów zasypie nas węgiel z Rosji. Padnie rekord importu surowca? Dziennik. http://gospodarka.dziennik.pl/news/artykuly/572265,wegiel-Z-rosji-rekord-import-surowiec.html. Accessed 31 May 2020. 
Bartek-Lesi, M., Dézsi, B., Diallo, A., Kácsor, E., Kerekes, L., Kotek, P. et al. (2019). A hazai nagykereskedelmi villamosenergia-piac modellezése és ellátásbiztonsági elemzése 2030-ig különbözö erömüvi forgatókönyvek mellett. Budapest: Regional Centre for Energy Policy Research. https://rekk.hu/downloads/projects/2019_Arampiac_REKK.pdf. Accessed 30 July 2019.

Bolcsó, D. (2019, June 21). A magyar kormány a rezsicsökkentés miatt blokkolta az uniós klímatervet. Index.hu. https://index.hu/techtud/2019/06/21/klimavaltozas_karbonsemlegesseg_europai_unio_2050_blokkolas_rezs i_rezsicsokkentes/. Accessed 21 June 2019.

Büki, G., \& Lovas, R. (Eds.). (2010). Megújuló energiák hasznosítása. Budapest: Hungarian Academy of Sciences.

Ciepiela, D. (2017, September 6). Koniec z budową nowych elektrowni węglowych w Polsce. WNP.PL. http://energetyka.wnp.pl/koniec-z-budowa-nowych-elektrowni-weglowych-w-polsce,305594_1_0_0.html. Accessed 1 June 2020.

Deák, A. (2018). Energiabiztonság. Budapest: National University of Public Service.

Dickel, R., El-Katiri, L., Hassanzadeh, E., Henderson, J., Honoré, A., Pirani, S., et al. (2014). Reducing European Dependence on Russian Gas: Distinguishing Natural Gas Security from Geopolitics (OIES Paper, NG 92). Oxford: Oxford Institute for Energy Studies. https://www.oxfordenergy.org/wpcms/wpcontent/uploads/2014/10/NG-92.pdf. Accessed 7 August 2019.

Dinya, L. (2010). Biomassza-alapú energiatermelés és fenntartható energiagazdálkodás. Magyar Tudomány, $171(8), 912-925$.

Dinya, L. (2018). Biomassza-alapú energiahasznosítás: a múlt és a jövő. Magyar Tudomány, 179(8), 11841196.

EASAC. (2018, June 15). Commentary by the European Academies' Science Advisory Council (EASAC) on Forest Bioenergy and Carbon Neutrality. https://easac.eu/fileadmin/PDF_s/reports_statements/Carbon_Neutrality/EASAC_commentary_on_Carbon Neutrality 15 June 2018.pdf. Accessed 1 June 2020.

EC. (2017). State Aid: Commission Clears Investment in Construction of Paks II Nuclear Power Plant in Hungary. https://ec.europa.eu/commission/presscorner/detail/en/IP_17_464. Accessed 5 June 2020.

EEA. (2020). CO2 Intensity of Electricity Generation. European Environment Agency. https://www.eea.europa.eu/data-and-maps/data/co2-intensity-of-electricity-generation. Accessed 4 June 2020.

EOP. (2014). The All-Of-the-Above Energy Strategy as a Path to Sustainable Economic Growth. Washington, DC: Executive Office of the President of the United States. https://obamawhitehouse.archives.gov/sites/default/files/docs/aota_energy_strategy_as_a_path_to_sustainab le_economic_growth.pdf. Accessed 4 June 2020.

European Parliament and Council. (2009). Directive 2009/28/EC of the European Parliament and of the Council of 23 April 2009 on the Promotion of the Use of Energy from Renewable Sources and Amending and Subsequently Repealing Directives 2001/77/EC and 2003/30/EC. http://eur-lex.europa.eu/legalcontent/en/ALL/?uri=CELEX-\%3A32009L0028. Accessed 2 June 2020.

European Parliament and Council. (2018). Directive (EU) 2018/2001 of the European Parliament and of the Council of 11 December 2018 on the Promotion of the Use of Energy from Renewable Sources (Text with EEA relevance). https://eur-lex.europa.eu/legal-content/EN/TXT/?uri=CELEX:32018L2001. Accessed 9 December 2019.

Eurostat. (2020a). Production of Electricity and Derived Heat by Type of Fuel. https://appsso.eurostat.ec.europa.eu/nui/show.do?dataset=nrg_bal_peh\&lang=en. Accessed 25 February 2020.

Eurostat. (2020b). Share of Energy from Renewable Sources. https://appsso.eurostat.ec.europa.eu/nui/show.do?dataset=nrg_ind_ren\&lang=en. Accessed 4 March 2020.

Eurostat. (2020c). Supply, Transformation and Consumption of Gas. https://appsso.eurostat.ec.europa.eu/nui/show.do?dataset=nrg_cb_gas\&lang=en. Accessed 24 May 2020.

Eurostat. (2020d). Supply, Transformation and Consumption of Electricity. https://appsso.eurostat.ec.europa.eu/nui/show.do?dataset=nrg_cb_e\&lang=en. Accessed 25 February 2020.

Friends Against Wind. (2016, March 8). Wind Industry in Poland Has Had 15 Years to Become a Responsible Partner for Rural Communities. Now It Cries Wolf at First Attempt of Proper Regulation. http://en.friendsagainst-wind.org/doc/SW_eu_Wind_lobby_in_Poland_wasted_15_years_8March2016.pdf. Accessed 1 June 2020.

Greenpeace Hungary. (2018). A Greenpeace Magyarország éghajlatvédelmi javaslatcsomagja. https://www.greenpeace.org/hungary/cikkek/3070/a-greenpeace-magyarorszageghajlatvedelmijavaslatcsomagja/. Accessed 20 July 2019. 
Hajto, M., Cichocki, Z., Bidłasik, M., Borzyszkowski, J., \& Kuśmierz, A. (2017). Constraints on Development of Wind Energy in Poland Due to Environmental Objectives. Is There Space in Poland for Wind Farm Siting? Environmental Management, 59(2), 204-217.

Heinrich, A., Kusznir, J., Lis, A., Pleines, H., Smith Stegen, K., \& Szulecki, K. (2016). Towards a Common EU Energy Policy? Debates on Energy Security in Poland and Germany. ESPRi.

https://www.forschungsstelle.uni-bremen.de/UserFiles/file/ESPRI_Policy_Paper_2 2016.pdf. Accessed 2 June 2020.

Hughes, L. (2012). A Generic Framework for the Description and Analysis of Energy Security in an Energy System. Energy Policy, 42, 221-231.

HVG.hu. (2017, December 27). Enyhit a napelemekre kivetett sarcon a kormány. http://hvg.hu/gazdasag/20171227_Enyhit_a_napelemekre_kivetett_sarcon_a_kormany. Accessed 31 May 2020.

IEA. (2020a). Energy Security. International Energy Agency. https://www.iea.org/topics/energysecurity/. Accessed 4 May 2020.

IEA. (2020b). Our Mission. International Energy Agency. https://www.iea.org/about/ourmission/. Accessed 4 May 2020.

IEO. (2017). Rynek fotowoltaiki w Polsce. Warsaw: Institute for Renewable Energy. https://www.cire.pl/pliki/2/2017/raportpv_2017_final_18_05_2017.pdf. Accessed 1 June 2020.

IEO. (2019). W 2019 roku Polska może znaleźć się już na 4 miejscu w UE pod względem rocznych przyrostów nowych mocy fotowoltaicznych. Warsaw: Institute for Renewable Energy. https://ieo.pl/pl/projekty/raportrynek-fotowoltaiki-w-polsce-2019. Accessed 5 March 2020.

Illés, J. (2017, September 27). Akár háromszor annyi turbina is müködhetne, de nem engedik az építésüket. Mno.hu. https://mno.hu/gazdasag/akar-haromszor-annyi-turbina-is-mukodhetne-de-nem-engedik-azepitesuket-2418865. Accessed 1 June 2020.

IRENA. (2019a). Renewable Capacity Statistics 2019. Abu Dhabi: International Renewable Energy Agency. https://www.irena.org/Imedia/Files/IRENA/Agency/Publication/2019/Mar/IRENA_RE_Capacity_Statistics_2019.pdf. Accessed 24 May 2020.

IRENA. (2019b). Renewable Power Generation Costs in 2018. Abu Dhabi: International Renewable Energy Agency. https://www.irena.org/-/media/Files/IRENA/Agency/Publication/2019/May/IRENA RenewablePower-Generations-Costs-in-2018.pdf. Accessed 24 May 2020.

ITM. (2020a). Magyarország Nemzeti Energia- és Klímaterve - 2-3. melléklet. Budapest: Ministry for Innovation and Technology. https://www.kormany.hu/hu/dok? source=11\&type=402\#! DocumentBrowse. Accessed 2 February 2020.

ITM. (2020b). Magyarország Nemzeti Energia- és Klímaterve. Budapest: Ministry for Innovation and Technology (ITM). https://www.kormany.hu/hu/dok? source=11\&type=402\#! DocumentBrowse. Accessed 2 February 2020.

ITM. (2020c). Nemzeti Energiastratégia 2030, kitekintéssel 2040-ig. Budapest: Ministry for Innovation and Technology (ITM). https://www.kormany.hu/hu/dok? source=11\&type=402\#! DocumentBrowse. Accessed 2 February 2020.

Jewell, J. (2011). The IEA Model of Short-Term Energy Security (MOSES): Primary Energy Sources and Secondary Fuels (IEA Energy Papers, 17). https://ideas.repec.org/p/oec/ieaaaa/2011-17-en.html. Accessed 4 August 2019.

Kamola-Cieślik, M. (2017). The Government's Policy in the Field of Hard Coal Mining Restructuration as an Element of Poland's Energy Security. Polish Political Science Yearbook, 46, 247-261.

Kerényi, A. Ö., \& Szeredi, I. (2012). A vízenergia-hasznosítás vizsgálata II. Magyar Energetika, 19(5), $37-41$.

Kotek, P., Selei, A., \& Takácsné Tóth, B. (2017). The Impact of the Construction of the Nord Stream 2 Gas Pipeline on Gas Prices and Competition. Budapest: Regional Centre for Energy Policy Research. https://rekk.hu/downloads/academic_publications/NordStream2_REKK.pdf. Accessed 25 April 2019.

Larson, A. (2018, February 28). King Coal Is Alive and Kicking in Poland. Power. http://www.powermag.com/king-coal-is-alive-and-kicking-in-poland/. Accessed 30 May 2020.

Lazard (2019, November 7). Levelized Cost of Energy and Levelized Cost of Storage 2019. https://www.lazard.com/perspective/lcoe2019. Accessed 10 April 2020.

Martewicz, M. (2020, February 14). Poland's Last New Coal Plant Could Be Built As Soon As This Year. Bloomberg. https://www.bloomberg.com/news/articles/2020-02-14/poland-s-last-new-coal-plant-could-bebuilt-as-soon-as-this-year. Accessed 14 February 2020.

Majewski, J., \& Szymanek, M. (2012). Technical, Economic and Legal Conditions of the Development of Photovoltaic Generation in Poland. Acta Energetica, 2(11), 21-26.

Majewski, W. (2013). The Development of Hydro Power in Poland: The Most Important Hydro Engineering Facilities. Acta Energetica, 3(16), 45-53. 
MAP. (2019). Scenariusz Polityki Energetyczno-Plimatycznej. Ocena skutków planowanych polityk $i$ środków. Załacznik 2. do Krajowego planu na rzecz energii i klimatu na lata 2021-2030. Warsaw: Ministry of State Assets. https://www.gov.pl/attachment/a8db078d-535b-4b1b-bfe5-bda64df73778. Accessed 2 March 2020.

Marczisovszky, M. (2020, February 19). Palkovics: 2025-től földgáz alapú lesz a Mátrai Erőmü. Index.hu. https://index.hu/gazdasag/2020/02/19/matrai_eromu_palkovics_bejelentette_foldgaz_alapu/. Accessed 19 February 2020.

Mátrai Erőmű. (2020). Mátrai Erőmü. Cégtörténet. http://www.mert.hu/cegtortenet. Accessed 2 June 2020.

McKinsey \& Company (2016). Developing Offshore Wind Power in Poland: Outlook and Assessment of Local Economic Impact. https://assets.mckinsey.com/pl/ /media/McKinsey/Locations/Europe$\% 20$ and $\% 20$ Middle $\% 20$ East/Polska/Raporty/Rozwoj\%20morskiej\%20energetyki\%20wiatrowej\%20w\%20 Polsce/Developing\%20offshore\%20wind\%20power\%20in\%20Poland\%20\%20report\%20in\%20English.ashx. Accessed 4 June 2020.

ME. (2010). National Renewable Energy Action Plan. Warsaw: Ministry of Energy. https://ec.europa.eu/energy/sites/ener/files/documents/dir_2009_0028_action_plan_poland.zip. Accessed 2 June 2020.

ME. (2018). Wnioski z analiz prognostycznych dla sektora energetycznego-załacznik nr 1 do Polityki energetycznej Polski do 2040 roku (PEP2040). Warsaw: Ministry of Energy. https://www.gov.pl/documents/33372/436746/Wnioski_z_analiz_do_PEP2040_2018-11-23.pdf/1481a6a9b87f-a545-4ad8-e1ab467175cf. Accessed 29 January 2019.

MEKH. (2019). 1,1 GW összteljesitményt értek el a napelemek 2019 közepére. Hungarian Energy and Public Utility Regulatory Authority. http://www.mekh.hu/1-1-gw-osszteljesitmenyt-ertek-el-a-napelemek-2019kozepere. Accessed 11 February 2020.

MEKH-Mavir. (2019). Data of the Hungarian Electricity System. Budapest: MEKH-Mavir. https://www.mavir.hu/documents/10258/154394509/MEKH_MAVIR+-+VER+kiadv\%C3\%A1ny+2018++web.pdf/cd611b23-9f7c-3e9b-da49-17d4916df10b. Accessed 10 April 2020.

MSZIT. (2011). A szélenergia támogatásáról, és a fogyasztói árakra gyakorolt hatásáról. Hungarian Wind Energy Industry Association. http://www.mszit.hu/hirek/hirek/article/a-szelenergia-tamogatasarol-es-afogyasztoi-arakra-gyakorolt-hatasarol/. Accessed 30 May 2020.

Munkácsy, B. (2015). Háttérinformációk és szempontok a szélerőmüvekkel kapcsolatos szabályozás tárgykörében. Budapest: ELTE University. http://munkacsy.web.elte.hu/szelenergia-hatter.pdf. Accessed 15 November 2018.

Munkácsy, B., Sáfián, F., Harmat, A., \& Németh, S. (2014). Hazai megújuló potenciálok és hasznosításuk jövőképünkben. In B. Munkácsy (Ed.), A fenntartható energiagazdálkodás felé vezető út (pp. 143-152). Budapest: ELTE University.

Nagy, G. M. (2016, September 1). Csak ne a szél! Miért sorvasztja el a kormány a szélerőmüveket? Magyar Narancs. https://magyarnarancs.hu/belpol/csak-ne-a-szel-100654. Accessed 30 May 2020.

Német, T. (2016, October 8). Csepreghy: a szélenergiának nincs helye a magyar energiarendszerben. Index.hu. http://index.hu/belfold/2016/10/08/csepreghy_a_szelenergianak_nincs_helye_a_magyar_energiarendszerbe n/. Accessed 30 May 2020.

NFM. (2010). National Renewable Energy Action Plan 2010-2020. Budapest: The Deputy Secretariat of State for Green Economy Development and Climate Policy for the Ministry of National Development. http://20102014.kormany.hu/download/6/b9/30000/RENEWABLE\%20ENERGY_REPUBLIC\%20OF\%20HUNGAR Y\%20NATIONAL\%20RENEWABLE\%20ENERGY\%20ACTION\%20PLAN\%202010_2020.pdf. Accessed 10 November 2018.

OAH. (2011). Nemzeti jelentés. Negyedik jelentés, készült a kiégett fütőelemek kezelésének biztonságáról és a radioaktív hulladékok kezelésének biztonságáról szóló közös egyezmény keretében. Budapest: Hungarian Atomic Energy Authority $(\mathrm{OAH})$.

https://www.haea.gov.hu/web/v3/OAHPortal.nsf/40A6C15B41C95EFAC1257BEB00306F10/\$FILE/nemzj el4.pdf. Accessed 11 June 2019.

Official Journal of the European Union. (2012). Consolidated Versions of the Treaty on European Union and the Treaty on the Functioning of the European Union. https://eur-lex.europa.eu/legalcontent/EN/TXT/HTML/?uri=CELEX:12012E/TXT\&from=HU. Accessed 6 May 2020.

Paks II. (2020). Background of the Project. https://www.paks2.hu/en/web/paks-2-en/background-of-the-project. Accessed 6 June 2020.

PSEW. (2016). The State of Wind Energy in Poland in 2015. Warsaw: The Polish Wind Energy Association. http://pliki.psew.pl/Marcin/Stan_energetyki_wiatrowej_w_Polsce_ENG.pdf. Accessed 2 April 2018.

PSG. (2017a). Import i eksport węgla kamiennego w Polsce. Polish Geological Institute. https://www.pgi.gov.pl/dokumenty-pig-pib-all/foldery-instytutowe/foldery-surowcowe-2018/6214-folderwegiel-kamienny-1/file.html. Accessed 7 May 2018. 
PSG. (2017b). Wydobycie węgla kamiennego w Polsce. Polish Geological Institute. https://infolupki.pgi.gov.pl/sites/default/files/czytelnia_pliki/1/georaport_wegiel_kamienny_2_1.pdf. Accessed 7 May 2018.

Schlandt, J. (2015, December 29). Loops and Cracks: Excess German Power Strains Europe's grids. Clean Energy Wire. https://www.cleanenergywire.org/news/loops-and-cracks-excess-german-power-strainseuropes-grids-0. Accessed 2 June 2020.

Schwartzkopff, J., \& Schulz, S. (2017). Climate \& Energy Snapshot: Poland. The Political Economy of the Low-Carbon Transition. https://www.e3g.org/docs/Climate_energy_snaphot_PL.pdf. Accessed 2 June 2020.

ŚCITT. (2020). Potencjal hydroenergetyczny i jego wykorzystanie. Regional Centre for Innovation and Technology Transfer. http://portalrsi.it.kielce.pl/pl/top/potencjal_hydroenergetyczny_i_je?. Accessed 12 March 2020.

Smil, V. (2010). Energy Transitions: History, Requirements, Prospects. Santa Barbara, CA: Praeger.

Smil, V. (2016). Examining Energy Transitions: A Dozen Insights Based on Performance. Energy Research and Social Science, 22, 194-197.

Statista. (2020). Total Installed Wind Power Capacity in Poland from 2008 to 2019. https://www.statista.com/statistics/421509/total-wind-power-in-poland/. Accessed 13 May 2020.

Steller, J. (2012). Hydropower Sector in Poland: Current Status and Outlook. Hidroenergia 2012. http://www.tew.pl/projekty/shpstreammap/HE_2012_0_01_steller_Hydropower_sector_in_Poland_1.pdf. Accessed 2 June 2020.

Steller, J. (2019). Hydropower in Poland: Looking Forward for a New Stimulus. Nordic Workshop: Lulea University of Technology. http://www.tew.pl/biblioteka/prezentacje/2019_Steller_Hydropower_in_Poland_Hydropower_Europe_Lule a 2019 wide.pdf. Accessed 12 March 2020.

Szabó, D. (2017, May 21). Elbukik a nagy terv. Magyarországra nem süt már a Nap. Napi.hu. https://www.napi.hu/magyar_vallalatok/elbukik_a_nagy_terv_magyarorszagra_nem_sut_mar_a_nap.63809 5.html. Accessed 18 November 2018.

Szalai, S., Gács, I., Tar, K., \& Tóth, P. (2010). A szélenergia helyzete Magyarországon. Magyar Tudomány, 171(8), 847-958.

Szczepiński, J. (2016). Aktualna sytuacja branży górnictwa węgla brunatnego w Polsce. Warsaw: Posiedzenie Parlamentarnego Zespołu Górnictwa i Energii. http://orka.sejm.gov.pl/opinie8.nsf/nazwa/390_20161103_2/\$file/390_20161103_2.pdf. Accessed 19 March 2018.

Szeredi, I., Alföldi, L., Csom, G., \& Mészáros, C. (2010). A vízenergia-hasznosítás szerepe, helyzete, hatásai. Magyar Tudomány, 171(8), 959-978.

Szulecki, K., Ancygier, A., \& Szwed, D. (2015). Energy Democratization? Societal Aspects of Decarbonization in the German and Polish Energy Sectors. ESPRi. http://ssrn.com/abstract=2575695. Accessed 2 August 2018.

Tóth, L., \& Schrempf, N. (2013). Szélerőmüvek szerepe “A megújuló energia hasznosítása” Nemzeti Cselekvési Tervben. Mezögazdasági Technika.

http://technika.gmgi.hu/uploads/termek_341/szeleromuvek_szerepe_a_nemzeti_cselekvesi_tervben_13 08. pdf. Accessed 2 June 2020.

Tóth, P., Bulla, M., \& Nagy, G. (2011). Energetika. https://regi.tankonyvtar.hu/hu/tartalom/tamop425/0021_Energetika/ch04s03.html. Accessed 4 June 2020.

Union of Concerned Scientists. (2013a, March 5). Environmental Impacts of Hydroelectric Power. https://www.ucsusa.org/clean_energy/our-energy-choices/renewable-energy/environmental-impactshydroelectric-power.html. Accessed 2 June 2020.

Union of Concerned Scientists. (2013b, March 5). Environmental Impacts of Solar Power. https://www.ucsusa.org/clean_energy/our-energy-choices/renewable-energy/environmental-impacts-solarpower.html. Accessed 2 June 2020.

Von Hippel, D., Suzuki, T., Williams, J. H., Savage, T., \& Hayes, P. (2011). Energy Security and Sustainability in Northeast Asia. Energy Policy, 39, 6719-6730.

Widera, M., Kasztelewicz, Z., \& Ptak, M. (2016). Lignite Mining and Electricity Generation in Poland: The Current State and Future Prospects. Energy Policy, 92, 151-157.

Wierzbowski, M., Filipiak, I., \& Lyzwa, W. (2017). Polish Energy Policy 2050: An Instrument to Develop a Diversified and Sustainable Electricity Generation Mix in Coal-Based Energy System. Renewable and Sustainable Energy Reviews, 74, 51-70.

WindEurope. (2018, April 11). Ambitious 8 GW of Offshore Wind Planned That Will Put Poland Back on Wind Energy Map. https://windeurope.org/newsroom/press-releases/ambitious-8gw-of-offshore-wind-plannedthat-will-put-poland-back-on-wind-energy-map/. Accessed 1 August 2018. 
WindEurope (2019, July 23). Revised Renewables Act Paves Way for 2.5 GW Onshore Wind Auction in Poland. https://windeurope.org/newsroom/news/revised-renewables-act-paves-way-for-2-5-gw-onshorewind-auction-in-poland/. Accessed 17 April 2020.

Wood, I., Danahy, J., \& Broom, R. (2017, June 15). Poland's Nuclear Plans Regain Some Momentum. https://www.squirepattonboggs.com/ /media/files/insights/publications/2017/06/polands-nuclear-plansregain-some-momentum/polandsnuclearplansregainsomemomentum.pdf. Accessed 31 May 2020.

Csaba Weiner is a Senior Research Fellow at the Institute of World Economics of the Centre for Economic and Regional Studies in Budapest, Hungary, which he joined in 2003 after graduating with his bachelor's degree in 2000 and master's degree in 2003, both in economics. His main areas of research interest are the energy sector in Central and Eastern Europe and the countries of the former Soviet Union; foreign direct investment in and from Russia; the Russian economy; and Russian-Hungarian relations. He earned his Ph.D. in Regional Science in 2011 and was awarded the János Bolyai Research Scholarship by the Hungarian Academy of Sciences for the period 2016-2019. Supported by the New National Excellence Programme of Hungary's Ministry of Human Capacities, Csaba Weiner was a Bolyai+ Teaching and Research Scholar at the Budapest Business School University of Applied Sciences during the 2018-2019 academic year. He has authored more than seventy publications and has been a speaker at some seventy conferences and workshops. 